\title{
Calcitization and Bulk Chemistry of Phosphate Grains from the Upper Part of Amman Formation, Southeast Irbid, Jordan
}

\author{
Saeb Al- Shereideh ${ }^{1}$, Walid Saqqa ${ }^{1}$, Nazem El-Radaideh ${ }^{1}$, Khalid Tarawneh ${ }^{2} \&$ Hani Alnawafleh ${ }^{2}$ \\ ${ }^{1}$ Department of Earth and Environmental Sciences, Faculty of Science, Yarmouk University, Amman, Jordan \\ ${ }^{2}$ Department of Mining and Mineral Engineering, Al-Hussein Bin Talal University, Ma'an, Jordan \\ Correspondence: Hani Alnawafleh, Department of Mining and Mineral Engineering, Al-Hussein Bin Talal \\ University, Ma’an, Jordan. Tel: 962-777-836-323. E-mail: Hanialnawafleh@ahu.edu.jo
}

Received: August 16, 2013 Accepted: September 15, 2013 Online Published: October 22, 2013

doi:10.5539/jgg.v5n4p16 URL: http://dx.doi.org/10.5539/jgg.v5n4p16

\begin{abstract}
Degradation and subsequent calcitization of phosphate grains from the upper part of the Late Cretaceous Amman Formation at southeast Irbid in northern part of Jordan have been petrographically verified. A number of calcitization patterns were observed. The variety in calcitization patterns reflects the replacing nature of calcite. Filamentous schizophytes are assisted, through borings, in early degradation of bone fragments into phosphomicrite fillings and dark envelopes (haloes) around grains. Calcitization process is more likely attributed to the availability of calcite, restriction of apatite formation, nature and composition of phosphate grains, varying $\mathrm{pH}$ of sediment and pore-fluids and physico-chemical conditions of the depositional site. Diagenetic replacement of phosphate grains by calcite as a result of calcitization process resulted in poorer grade of phosphate deposits where the $\mathrm{P}_{2} \mathrm{O}_{5}$ is less than $15.2 \%$.
\end{abstract}

Keywords: Jordan, amman formation, phosphate grains, calcitization, diagenetic

\section{Previous Studies and Geologic History}

The nomenclature 'Amman Formation' was used for the first time by Masri (1963). The Upper Cretaceous (Early Santonian- Early Maastrichtian) Amman Formation covers large areas of Jordan stretching from the northern parts of Irbid district in the north to El-Shidiya in the southern part of Jordan (Mustafa et al., 1998). The base of the formation is defined at the boundary between the underlying chalk of Wadi Umm Ghudran Formation and the earliest existence of chert beds above. The basal boundary indicates a transgressive phase and deepening of the sea ground, followed by an influence of upwelling currents in the area. This explanation is confirmed by the findings of large shark teeth and bone fishes in the upper parts of Wadi Umm Ghudran Formation (Mustafa, 2000), and selachian fish remains in the Amman Formation (Zalmout \& Mustafa, 2001). The upper boundary is gradational and is marked by an increase of phosphate beds, marl and limestone with decrease of thickly-bedded chert, resulting in a marked break of slope with the softer marl and marly limestone of the overlying Muwaqqar Formation. Amman Formation is equivalent to the B2a (basal part rich in chert) and B2b (upper part rich in phosphate) of Wolfart (1959), the middle part of Amman Formation of Masri (1963), the lower part (B2a) of the B2 Silicified Limestone and Phosphate Formation of MacDonald and Partners (1965) and the lower part of Amman Formation of Parker (1970). Bender (1974) renamed Amman Formation as 'Silicified Limestone' Unit (basal part) and the 'Phosphorite' Unit (upper part) (Table 1).

Amman Formation consists of thin to thickly-bedded heterogeneous lithologies. These are predominantly gray, white or brown chert exhibiting a variety of texture ranging from homogenous, brecciated and nodular interbedded with limy mud, fossiliferous and dolomitic limestone, oyster-coquinal grainstone/rudstone, marl, chalky marl and chalk changing upward into bedded phosphates, phosphatic marl and phosphatic chert. The formation is very distinguished from the surrounding formations by the undulations of strata. The phosphate deposits of the upper part of Amman Formation cover vast areas of Jordan in the form of a phosphorite belt which extends of more than $300 \mathrm{~km}$ from El-Shidiya in the south to Wadi Sama El-Rusan in the north (Mustafa et al., 1998). Phosphate distribution in Jordan is illustrated in Figure 1. 
Table 1. A nomenclature of the upper cretaceous rock unites in Jordan

\begin{tabular}{|c|c|c|c|c|c|c|}
\hline Period & Epoch & Age & Group & $\begin{array}{c}\text { Members } \\
\text { (Bender, 1974) }\end{array}$ & $\begin{array}{c}\text { Formations (Masri, } \\
1963 \text { ) }\end{array}$ & $\begin{array}{c}\text { Symbols } \\
\text { (Macdonald } \\
1965)\end{array}$ \\
\hline & & Paleocene & \multirow{4}{*}{$\frac{\pi}{0}$} & Chalk Marl & Muwaqqar & B3 \\
\hline \multirow{9}{*}{ 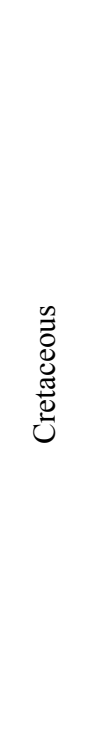 } & \multirow{8}{*}{ 营 } & Maastrichtian & & Phosphorite & \multirow{2}{*}{ Amman } & \multirow{2}{*}{ B2 } \\
\hline & & Campanian & & $\begin{array}{c}\text { Silicified } \\
\text { Limestone }\end{array}$ & & \\
\hline & & $\begin{array}{c}\text { Santonian-Coniaci } \\
\text { an }\end{array}$ & & \multirow[b]{2}{*}{$\begin{array}{l}\text { Massive } \\
\text { Limestone }\end{array}$} & Ghudran & B1 \\
\hline & & Turonian & \multirow{5}{*}{$\stackrel{\Xi}{\stackrel{\Xi}{Z}}$} & & Wadi Es Sir & A7 \\
\hline & & & & \multirow{2}{*}{$\begin{array}{l}\text { Echonoidal } \\
\text { Limesone }\end{array}$} & Shueib & A5-6 \\
\hline & & & & & Hummar & A4 \\
\hline & & & & \multirow{2}{*}{$\begin{array}{l}\text { Nodular } \\
\text { Limestone }\end{array}$} & Fuhais & A3 \\
\hline & & & & & Naur & A1-2 \\
\hline & \multicolumn{3}{|l|}{ Early } & \multicolumn{2}{|c|}{ Kurnub Sandstone } & \\
\hline
\end{tabular}

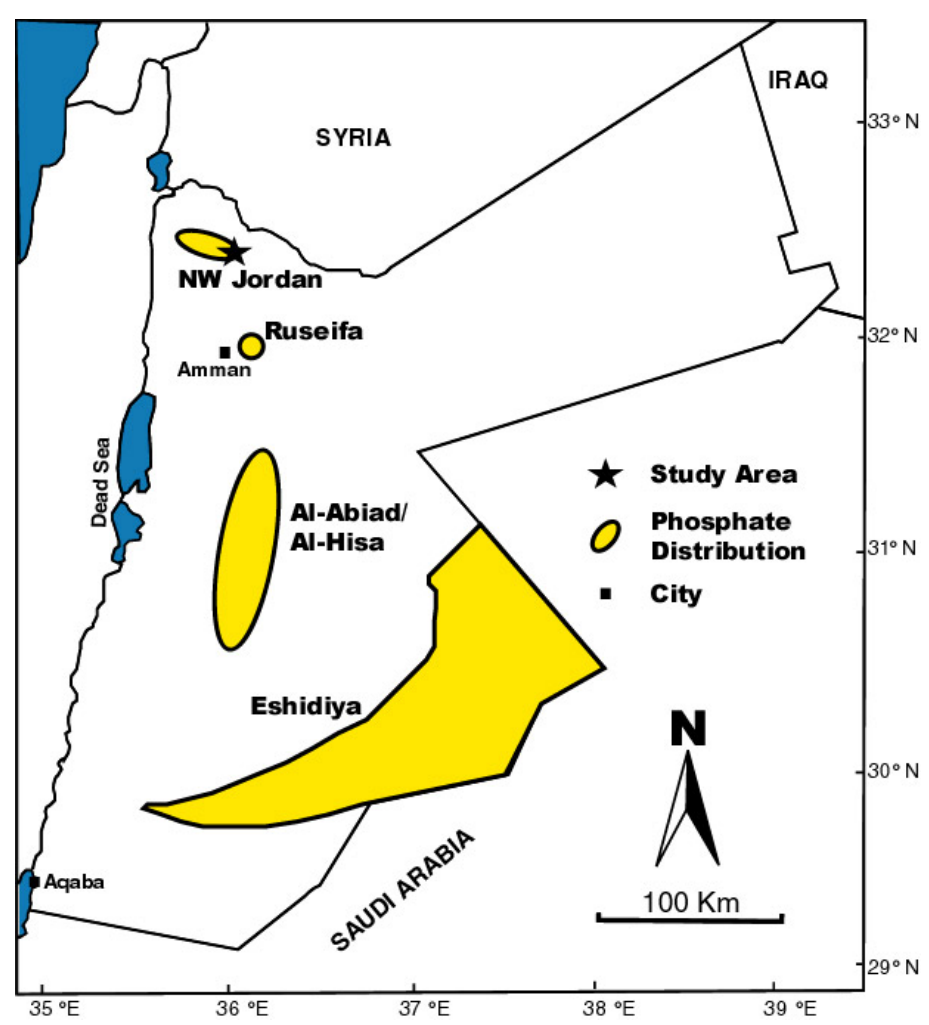

Figure 1. Phosphate distribution in Jordan. Figure reconstructed and modified from Pufahl et al. (2003)

Microfacies and geochemistry of phosphate deposits in southeast region of Irbid, north Jordan were studied by Al-Shereideh et al. (1997). The later authors identified two microfacies types: the phosphatic intraclastic foraminiferal molluscan wackstone-packstone (SMF-8 and SMF-9 of Wilson, 1975) as a shallow open marine 
platform facies rich in bone fragments and vertebrate teeth, while the second microfacies is phosphatic grainstone (SMF-14 of Wilson, 1975) with bone fragments, vertebrate teeth and phosphatized intraclasts and peloids cemented by sparite and microspar. Both facies are greatly affected by calcitization, calcite fillings and silicification. Mineralogical studies of the Jordanian phosphate deposits showed that these deposits consist chiefly of francolite (Saadi, 1969; Al-Agha, 1985; Fakhoury, 1987; Abed \& Al-Agha, 1989; Mustafa et al., 1998). The role of microorganisms, specially bacteria, genesis and mineralogy of phosphate deposits were studied by several authors. Globular structures, microbial tubules and filamentous meshwork postulated to have formed by bacterial activity (Soudry, 1987; Abed \& Fakhouri, 1990; Abdel Rahman \& Mansour, 2005). In contrary to phosphatization, diagenetic replacements of phosphate grains received little attention (Soudry, 1985). Some researchers (Kolodny, 1969; Cook, 1970; Russel \& Treuman, 1971; Lucas et al., 1979) studied different forms of diagenetic calcitization and silicification of phosphate from different regions and ages. Soudry (1985) described and named several patterns of phosphate grains calcitization and demonstrated its role in the depletion of the Naqab Phosphorite. An attempt has been made by Khaldoun et al. (2010) for defining and classifying the phosphorites of middle East with precise definition and description of phosphate components based on external shape and internal structure of Late Cretaceous and Paleogene phosphorite deposits of the east Mediterranean.

The Jordanian phosphorite belt is a part of the Arabian Phosphogenic Province between the Atlantic coast and Turkey (Notholt, 1980; Sheldon, 1987; Glenn et al., 1994a; Mustafa et al., 1998; Abdel Rahman \& Mansour, 2005). It has been developed at the southern margins of the Tethyan geosynclines during the Late Cretaceous - Paleogene times (Mustafa et al., 1998). A review of literatures on the Amman Formation suggests that this rock unit is intensively chertified in topographically highland areas, whereas in the eastern lowlands the rock unit is being less affected by silicification and yields the economic phosphate deposits of Jordan (Al-Rifaiy \& Al-Zamel, 1993; Abed, 1994). The present study aims to investigate and describe post-depositional diagenetic patterns of phosphate grains from the upper part of Late Cretaceous Amman Formation, southeast Irbid, north of Jordan.

\section{Field Work and Methodology}

Two columnar sections of the upper part of Amman Formation (B2b) were measured and described at Wadi Al-Mizraq (sections 1 and 2) in the study area (Figure 2). Phosphates are interbedded with dark brown brecciated chert limestone, calcareous marl and phosphatic limestone of different thicknesses (Figure 3). The visual grains size of phosphate grains ranges between pebbles and coarse silt. Twenty-four samples were collected from phosphate beds from the two columnar sections. The samples are thin-sectioned and studied under the polarized microscope to investigate the diagenetic calcitization patterns of phosphate particles. Quantitative analysis of selected major and minor elements for five samples from the study area was obtained by X-ray fluorescence (XRF) method at Department of Earth and Environmental Lab Yarmouk University.

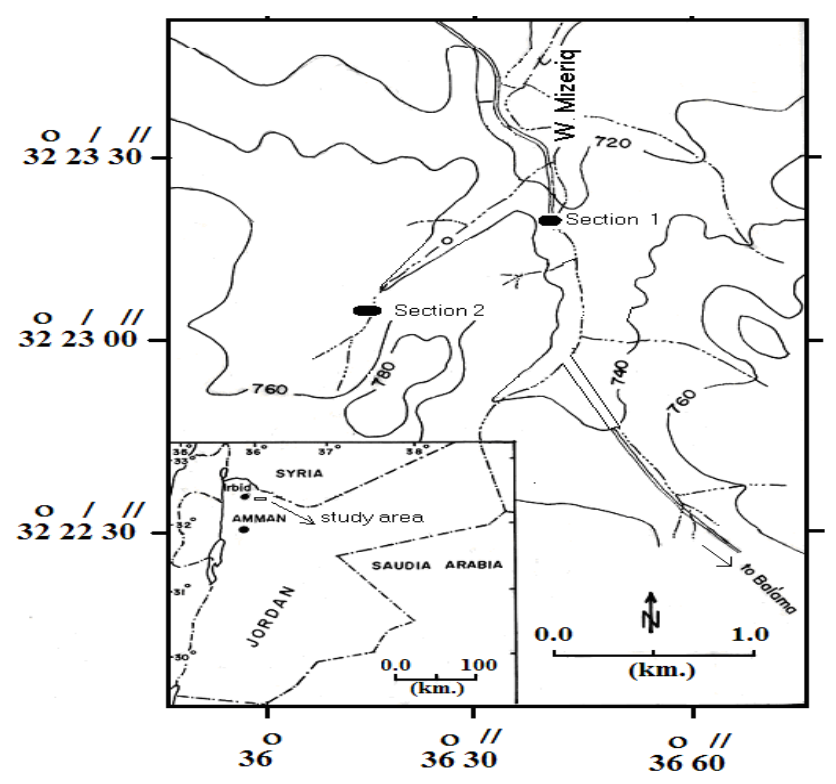

Figure 2. Detail location map of the study area where two sampled sections are illustrated 


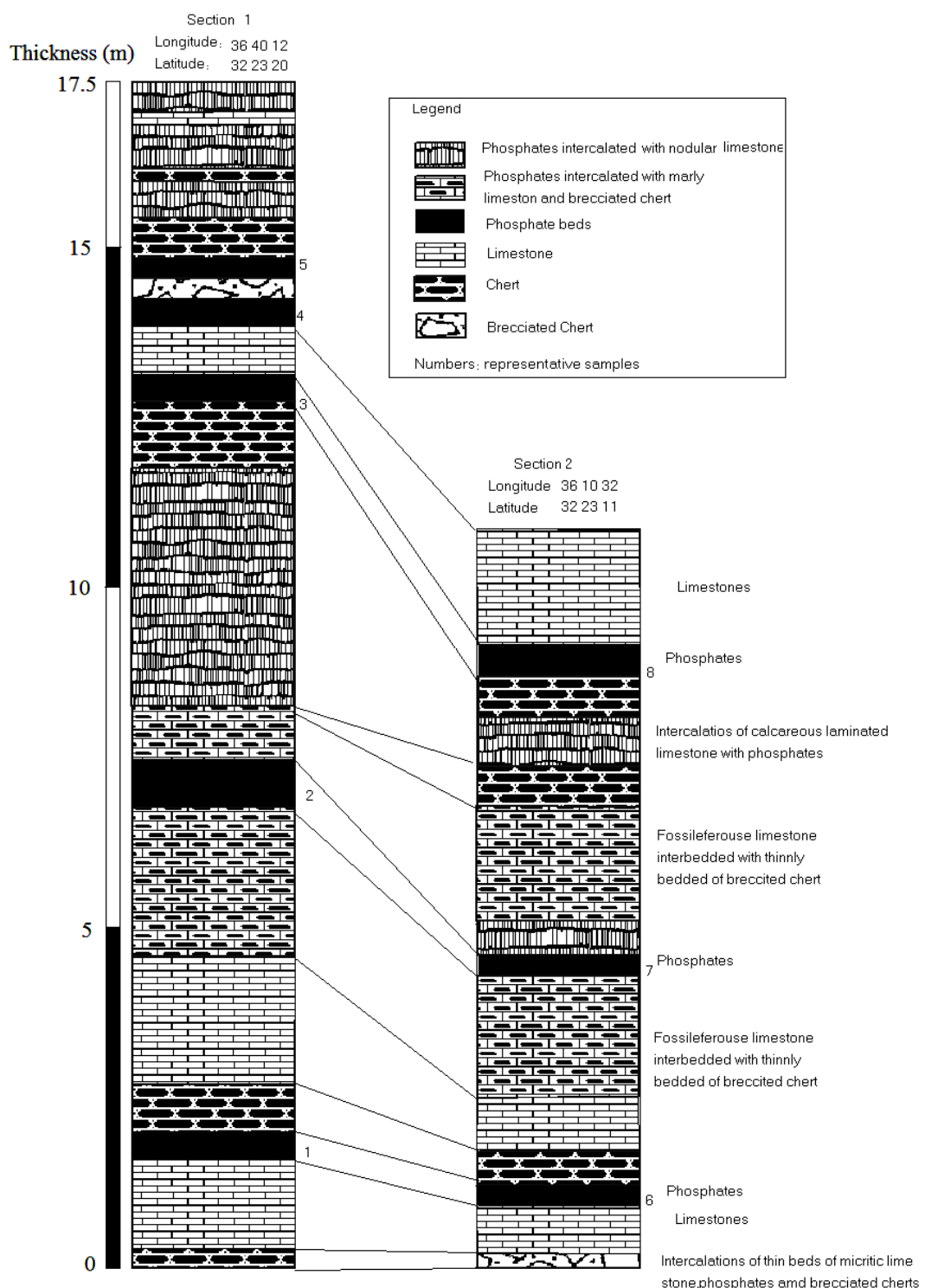

Figure 3. Columnar sections of the study area

\section{Results and Discussion}

\subsection{Phosphates Chemistry}

Representative samples of the phosphate rock were chemically analyzed to identify their major and trace element composition. The analytical results are shown in Table 2 and Table 3 respectively. It is well known that the phosphate deposits exhibit variable enrichments in certain major, minor and trace elements worldwide (Plank \& Langmuir, 1998). In general, in the studied samples, the $\mathrm{P}_{2} \mathrm{O}_{5}$ content ranges from 11.0 to $14.1 \%$, combined with high $\mathrm{SiO}_{2}$ and $\mathrm{CaO}$ amounts which range from 29.0 to $32.1 \%$ and from 51.0 to $58.1 \%$, respectively. High values of high $\mathrm{SiO}_{2}$ and $\mathrm{CaO}$ are due to the predominance of calcification and silicification processes in their bulk composition. Other oxides relatively have low percentages. Trace elements enrichment were observed and detected in phosphate samples. Sr content ranges between 300 to $1500 \mathrm{ppm}, \mathrm{Ba}$ content is range between 83 and $260 \mathrm{ppm}$ and $\mathrm{Zn}$ from 150 to $300 \mathrm{ppm}$, while other elements as As, Cd, Mn, Cu and V have less amount. The presence of these trace elements could be related to authigenic and diagenetic processes of phosphate or may be related to the presence of lenticular beds of clay-rich phosphate rocks that are intercalated within the studied sequence. 
Table 2. Chemical analyses (Major element oxides) of representative phosphate samples from the study area

\begin{tabular}{ccccccccc}
\hline Major & Sample & Sample & Sample & Sample & Sample & Sample & Sample & Sample \\
Oxides \% & 1 & 2 & 3 & 4 & 5 & 6 & 7 & 8 \\
\hline $\mathrm{SiO}_{2}$ & 30.1 & 35.2 & 29.0 & 30.1 & 30.5 & 29.0 & 30.0 & 30.0 \\
$\mathrm{Al}_{2} \mathrm{O}_{3}$ & 0.05 & 0.4 & 0.1 & 0.01 & 0.1 & 0.1 & 0.04 & 0.04 \\
$\mathrm{Fe}_{2} \mathrm{O}_{3}$ & 0.1 & 0.9 & 0.1 & 0.2 & 0.1 & 0.1 & 0.4 & 0.4 \\
$\mathrm{TiO}_{2}$ & 0.1 & 0.2 & 0.1 & 0.02 & 0.1 & 0.2 & 0.2 & 0.1 \\
$\mathrm{MgO}$ & 1.3 & 0.4 & 1.0 & 0.10 & 0.1 & 1.0 & 0.5 & 0.5 \\
$\mathrm{CaO}$ & 58.1 & 51.0 & 53.1 & 57.0 & 58 & 53.0 & 53.0 & 53.0 \\
$\mathrm{Na}_{2} \mathrm{O}$ & 0.1 & 1.3 & 0.2 & 0.10 & 0.1 & 0.2 & 0.20 & 0.20 \\
$\mathrm{P}_{2} \mathrm{O}_{5}$ & 11.1 & 11.0 & 15.2 & 11.1 & 10.9 & 15.2 & 14.0 & 14.1 \\
\hline
\end{tabular}

Table 3. Chemical analyses (Trace elements) of representative phosphate samples from the study area

\begin{tabular}{ccccccccc}
\hline $\begin{array}{c}\text { Trace } \\
\text { elements } \\
(\mathrm{ppm})\end{array}$ & $\begin{array}{c}\text { Sample } \\
1\end{array}$ & $\begin{array}{c}\text { Sample } \\
2\end{array}$ & $\begin{array}{c}\text { Sample } \\
3\end{array}$ & $\begin{array}{c}\text { Sample } \\
4\end{array}$ & $\begin{array}{c}\text { Sample } \\
5\end{array}$ & $\begin{array}{c}\text { Sample } \\
6\end{array}$ & $\begin{array}{c}\text { Sample } \\
7\end{array}$ & $\begin{array}{c}\text { Sample } \\
8\end{array}$ \\
\hline $\mathrm{As}$ & 35 & 18 & 5 & 6 & 5 & 13 & 22 & 11 \\
$\mathrm{Ba}$ & 260 & 110 & 107 & 83 & 84 & 200 & 102 & 90 \\
$\mathrm{Cd}$ & 44 & 88 & 20 & 77 & 70 & 53 & 21 & 53 \\
$\mathrm{Cr}$ & 98 & 86 & 156 & 25 & 25 & 111 & 100 & 77 \\
$\mathrm{Mn}$ & 12 & 13 & 22 & 31 & 30 & 15 & 20 & 24 \\
$\mathrm{Sr}$ & 1500 & 600 & 750 & 690 & 605 & 700 & 650 & 300 \\
$\mathrm{Cu}$ & 14 & 15 & 17 & 15 & 14 & 17 & 16 & 17 \\
$\mathrm{~V}$ & 100 & 72 & 19 & 33 & 100 & 72 & 19 & 41 \\
$\mathrm{Zn}$ & 200 & 300 & 300 & 120 & 150 & 200 & 220 & 100 \\
\hline
\end{tabular}

\subsection{Detail of Internal Texture}

The results of petrographic studies that have been carried out on thin-sectioned phosphate samples indicated and displayed different types of phosphatic and non-phosphatic grains that are embedded in a matrix/cement of calcium carbonate, silica and microsphorites. Phosphatic grains are diverse and occur in different proportions. They include intraclasts usually of coarse silt and sand sizes, but in some cases they may reach up to several millimeters with angular to subangular or irregular shapes, peloids of different sizes from $0.1 \mathrm{~mm}$ to $0.6 \mathrm{~mm}$, mainly rounded or ovoid in shape. Bone fragments have retained some internal structures and are commonly of sand size but they may reach up to several millimeters of granule to pebble size. A high proportion of up to $75 \%$ of bone fragments display phosphomicrite tubule-fillings and dark grey envelopes produced by microphyte borings (Figure 4). Fecal pellets, vertebrates teeth and fish scales are rare. The intraclasts and peloids may incorporate inclusions of dark organic matter and probably small crystals of pyrite (Figure 5). The non-phosphatic materials are composed of chert fragments, mollusc shell debris, foraminiferal tests, relicts of echinoidal fragments and spines. Detrital quartz, pyrite and irregular patches of black carbonaceous matter are observed within the matrix. The matrix/cement material consists of micrite, microspar (4-10 $\mu)$ and sparry calcite with fine granular, equant drusy, blocky or poikilotopic textures also have been observed. Silica cement occurs as microcrystalline quartz and fibrous chalcedony. Microsphorites are resulted from the degradation of phosphatic grains and form initial envelopes around grains and tubule-fillings. Iron oxides may discolor phosphate grains, disseminate in matrix or fill intraparticle fractures. 


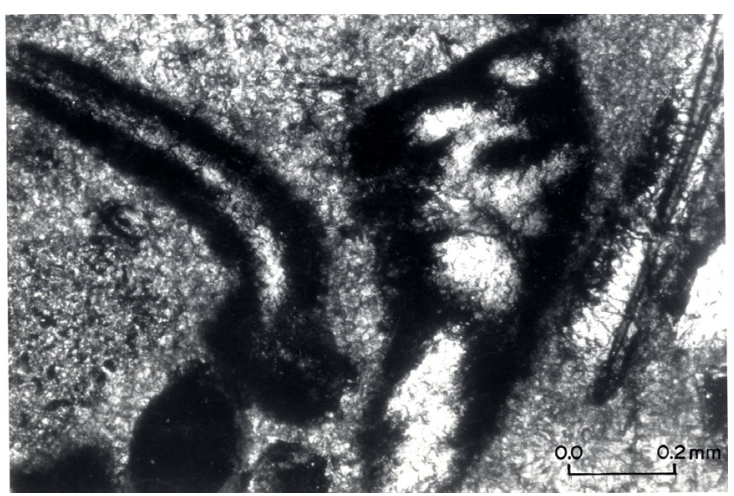

Figure 4. Bone fragments shows advanced stage of calcitization controlled by early destructively-generated envelopes. Phosphate grains are supported with microcrystalline quartz possibly replacing early calcium carbonate cement (PPL)

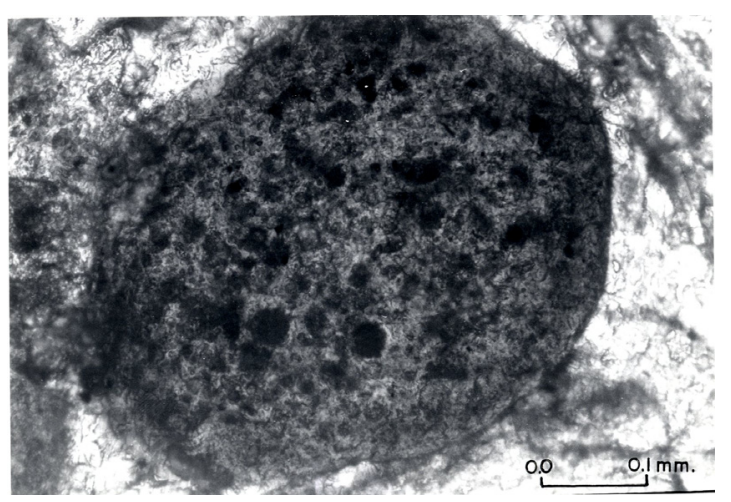

Figure 5. Rounded phosphate peloid grain with calcite stringers (light-colored) and patches of dark organic matter. Initial corrosion is discernable on outer rim of grain (PPL)

\subsection{Calcitization Patterns}

Calcitization of various patterns of phosphate grains were detected. Their elative distribution is presented in Table 4. The terms used in the description of calcitization patterns are basically according to Soudry (1985). Calcitization patterns include the following types:

Type (I): Spary calcite rims and calcite fingers post-dating the corrosion of phosphate grain margins. Corrosion leaves beyond very irregular grains lined with relatively thick calcite rims. Calcite fingers extend inward away from the outer surfaces (Figure 6). This feature is more common in the form of intraclasts. The degraded phosphate material (microsphorites) acts more likely as a matrix or forms dark veneer around grains.

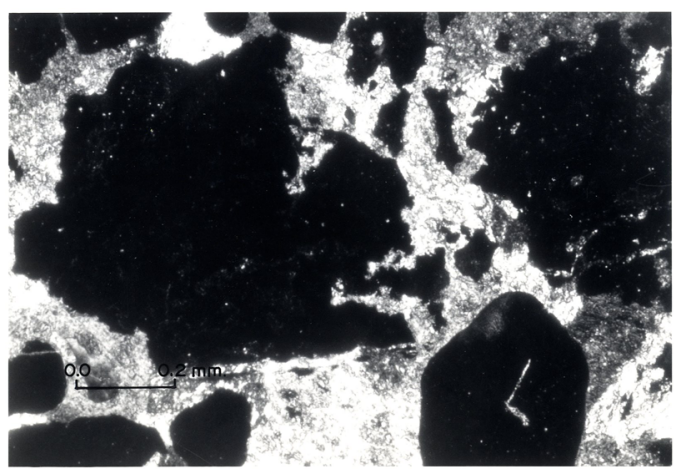

Figure 6. Advanced calcitization of two coarse phosphate grains (middle and upper right) evident by high corrosion of outer rims leaving beyond sutured and very irregular outer surfaces with development of calcite fingers growing inward (XPL) 
Table 4. Relative distribution of calcitization patterns obtained from petrographic study

\begin{tabular}{|c|c|c|c|c|c|}
\hline $\begin{array}{l}\text { Calcitization } \\
\text { Type }\end{array}$ & $\begin{array}{c}\text { Frequent } \\
\text { (Very common) }\end{array}$ & Common & Rare & $\begin{array}{l}\text { Very } \\
\text { rare }\end{array}$ & Comments \\
\hline Type I & $\times$ & & & & $\begin{array}{c}\text { Cover } \approx 80 \% \text { of studied samples. } \\
\text { Characterize bones, peloids, } \\
\text { intraclasts }\end{array}$ \\
\hline Type II & $x$ & & & & $\begin{array}{l}\text { Observed in all studied samples. } \\
\text { Mainly characterize intraclasts and } \\
\text { peloids }\end{array}$ \\
\hline Type III & & $x$ & & & $\begin{array}{l}\text { Cover } \approx 60 \% \text { of studied samples. } \\
\text { Observed mainly in peloids }\end{array}$ \\
\hline Type IV & & $x$ & & & $\begin{array}{c}\text { Cover } \approx 40 \% \text { of studied samples. Best } \\
\text { observed in intraclasts }\end{array}$ \\
\hline Type V & & & $\times$ & & $\begin{array}{l}\text { Cover } \approx 40 \% \text { of studied samples. } \\
\text { Found in all grain types }\end{array}$ \\
\hline Type VI & & & $\times$ & & Poorly developed \\
\hline Type VII & & & & $x$ & Occasionally observed \\
\hline
\end{tabular}

Type (II): Calcite front (in-place-replacement) invades phosphate grains preferentially from one side and extends inward towards the center of the grain. Calcite front consists of drusy calcite spars replacing intraclasts, peloids and bone fragments. The coarse, mosaic, and bladed calcite was precipitated and fill most of phosphates and bioclasts grains, rarely, the calcite was replaced by minor chalcedony and quartz as a late digenetic phenomena. Wilson et al. (2003) observed where bladed calcite occurs, silica is typically minor (Figures 7 and 8). The calcite crystals are typically increased in size towards the center of empty space and displayed concavo-convex contact. Bathurst (1976) attributed the commonly curved intercrystalline boundaries of mosaic spars, the gradual increase of crystal size, and the rarity of enfacial junctions among triple junction points to recrystallization through aggrading neomorphic process.

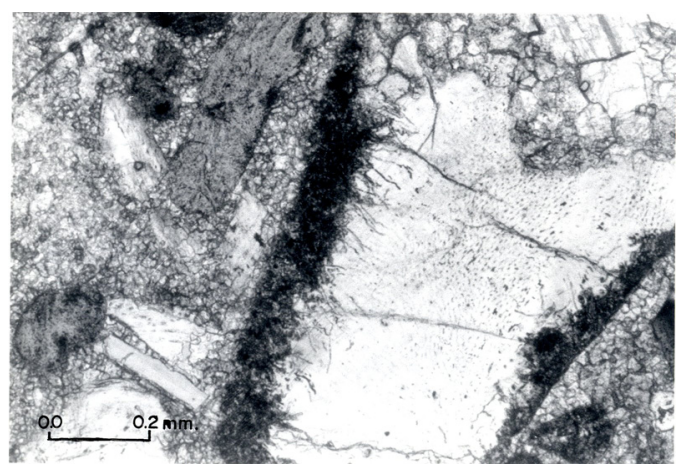

Figure 7. Large bone fragment (right) subjected to non-centripetal calcitization of calcite front type (upper right) made of drusy coarse calcite spar towards the center of cavity. Dark-grey envelop of microphyte borings is around the non-infested part of bone fragment (PPL) 


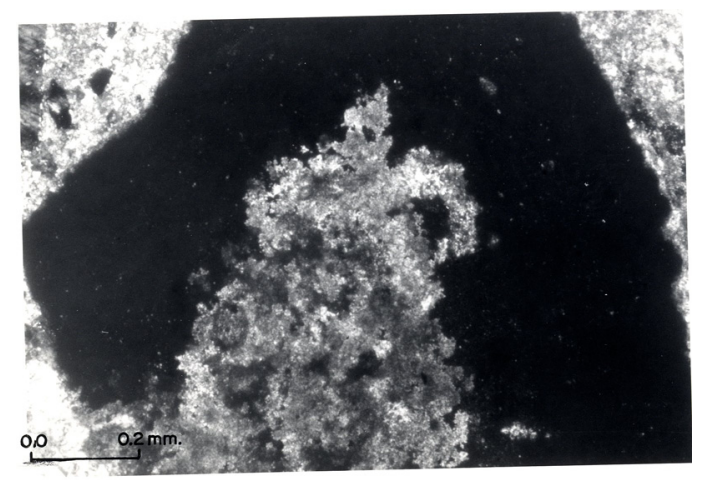

Figure 8. Large phosphate grain displays calcite front (non-centripetal calcitization) in middle lower part. Contact between calcite front and hosted grain has irregular forms (XPL)

Type (III): Degradation of phosphate grains and concurrent formation of centripetal micrite rims (Figure 9). Centripetal calcitization has to replace the whole periphery of phosphate grains as well as in peloids and intraclasts by microcrystalline calcite.

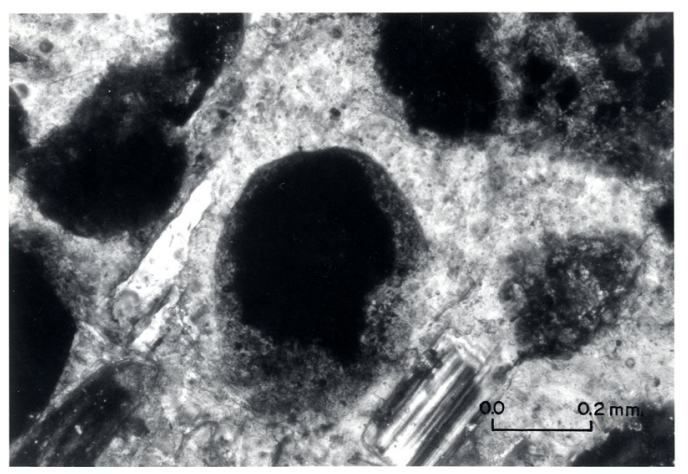

Figure 9. Centripetal calcitization of isotropic phosphate grain (center) with development of invaded micrite rim of a non-uniform thickness around grain (XPL)

Type (IV): Spary calcite veins cross-cutting the groundmass of matrix in preferred direction. Soudry (1985) explained this phenomenon in a view of diagenetic alteration.

Type (V): sporadic worm-like calcite stringers and irregular calcite patches are frequent in intraclasts, peloids and other coated grains (Figure 10).

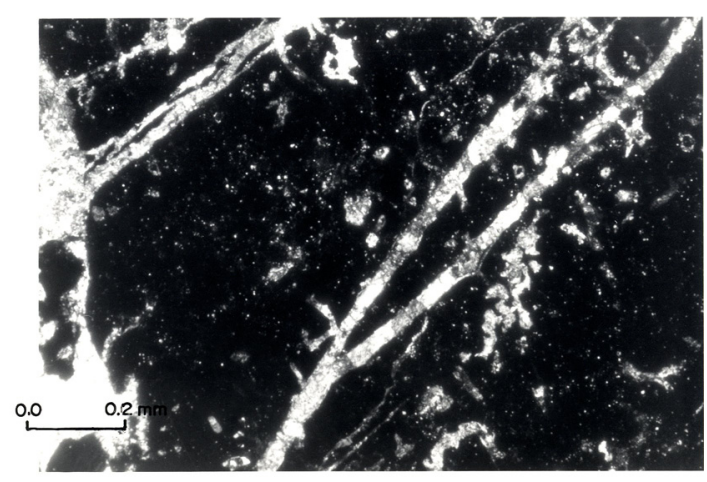

Figure 10. Sparite veins of calcite cross-cutting, large isotropic phosphate intraclast, and calcite stringers

(worm-like) (lower right) and dispersed calcite patches (XPL) 
Type (VI): Recrystallization of outer micrite rims of phosphate grains (phsphoclasts) in the form of coarse mosaic calcite (Figure 11), more likely developed as a late stage of replacement (Khaldoun et al., 2010).

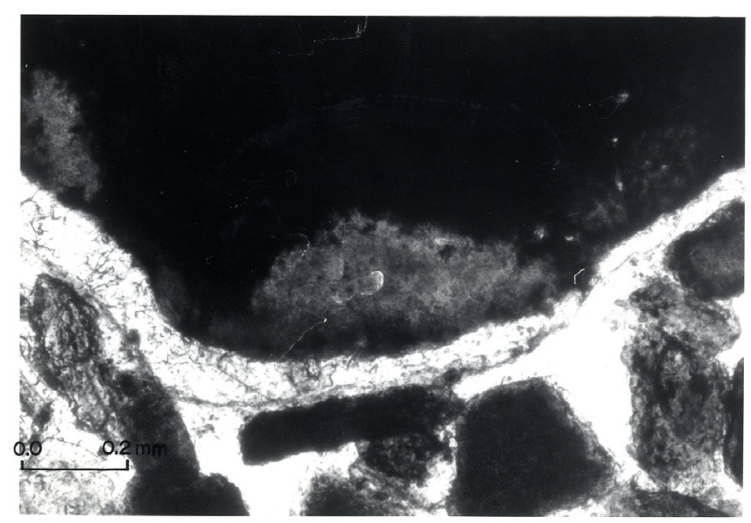

Figure 11. Large isotropic phosphate intraclast (upper) enclosed by recrystallized calcite rim of a mosaic spar texture. Intergranular pores are filled with amorphous silica in late stage (PPL)

Type (VII): Pervasive calcitization of phosphate grains more likely initiated by progressive development of dense micrite envelopes by microbial borings and calcite-infilling producing wholly micritized or calcitized phosphatic grains with the obliteration of the original internal structures (Figures 3 and 12). Unlike calcitization, diagenetic silicification of phosphate grains is less frequent and represented by selective silicification of peloids and in matrix.

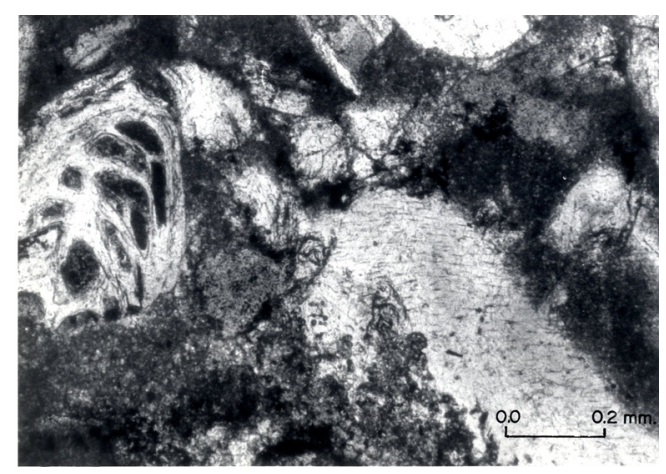

Figure 12. None-centripetal calcitization of two bone fragments (lower right and upper left). Grains although calcitized still retain some original internal structures (PPL)

The results of the present study agreed with observation of Soudry (1985). The majority of the examined phosphate grains experienced various types of calcitization and only a few grains remained intact or slightly infested (e.g. bone fragments in Figure 13). The diversity in calcitization patterns may be attributed to the composition of phosphate grains, chemistry of pore-fluid, contribution of microorganisms and physico-chemical conditions of the depositional environment. The intergrowths of phosphate minerals and organic matter in the biogenic hard parts promote preservation; however degradation may take place by microbial activity and filamentous schizophyte borings altering bone fragments into phosphomicrite matrix or aggregated peloids. 


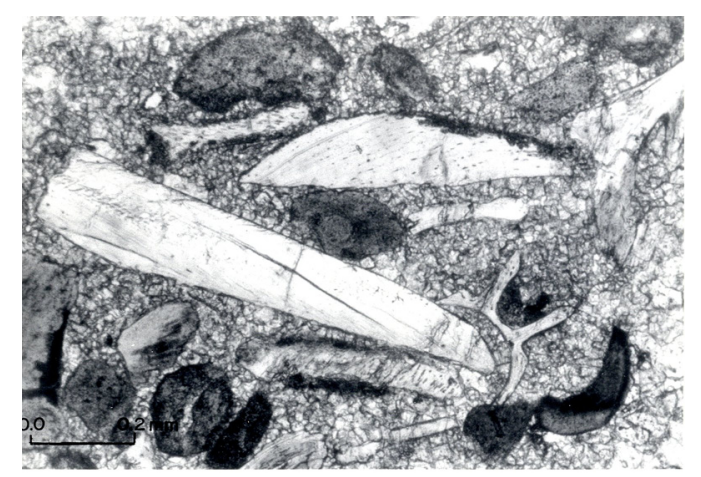

Figure 13. Unaltered bone fragments (center) and phosphate peloids (lower left). Some grains display incipient microsphorites envelopes (PPL)

Phosphatization may be the late diagenetic processes and may replace the original organization of peloids or coating of the external clast surfaces (Bathurst, 1971; Soudry, 1979; Feng \& Sun, 2003). Porous bones are more susceptible to degradation than teeth, since the latter are denser and almost protected by non-collagenous enamel (lucas \& Prévôt, 1991). The study of Prévôt (1990) confirmed preservation of upper enamels of shark teeth in phosphorites of North Africa, whereas bony bases are almost missing. Dissolution of phosphate grains particularly in marine environment may be prompted by tunneling microorganisms whose acid metabolites dissolve both mineral and organic matter (Piepenbrink, 1989). Microphyte borings of bones and fine-grained nature of peloids may enhance dephosphatization (Soudry, 1979, 1983). The large surface area of microcrystalline apatite in hard skeletons and the poorly-developed crystal form of biogenic hydroxyapatite accelerate their solubility which is $10^{4}$ times higher than the solubility of stoichiometric hydroxyapatite (Nriagu, 1983; Posner et al., 1984). Apatite starts to dissolve after carbonate dissolution by removal of calcium from apatite (Lucas et al., 1979) by interstitial waters saturated with calcium and depleted in phosphorus (Berner, 1980). Also, Glenn et al. (1988) related the slow down of apatite (Carbonate Fluor Apatite, CFA-type) precipitation to former dissolution and concentration of carbonate in anoxic pore-waters. This assumption is congruent with experimental results done by LeGeros et al. (1967) and Jahnke (1984) proposing interference of apatite crystallization and carbonate substitution which may increase the solubility of phosphate mineral. An increase in the $\mathrm{pH}$ of pore-waters reduced the stability field of apatite and increased it for calcite (Nathan \& Sass, 1981; Glenn et al., 1988). The variations in $\mathrm{pH}$ and the presence of $\mathrm{CO}_{2}$ during bacterial decay of organic matter are possibly essential in promoting the required changes in phosphate grains (Cook, 1970). Glenn et al. (1988) attributed the variation of $\mathrm{CO}_{2}$ concentration in marine waters to varying rates of organic matter decay. Concomitant dissolution-precipitation processes, perhaps via a $\mathrm{CO}_{2}$-bearing solution film at intercrystalline boundaries (Bathurst, 1976) may play also essential role in the development of calcitization patterns that revealed in this study.

\section{Conclusion}

Petrographic study was so helpful in investigating the degradation and calcitization of phosphate grains from the upper part of Amman Formation which exposed in the southeast region of Irbid, north Jordan. Microsphorites resulted from degradation processes are more likely a source of matrix and create dark veneers around phosphate grains. calcitization included micrite to sparry calcite rims or haloes around degraded phosphate grains, calcite fingers and sporadic worm-like calcite stringers, irregular calcite patches, coarse-drusy calcite front and calcite veins cross-cutting the matrix. There is no doubt that the process of calcitization and to less extent silicification of phosphate grains assisted in lowering the ratio of $\mathrm{P}_{2} \mathrm{O}_{5}$ in the investigated phosphates. The calculated ratio of $\mathrm{P}_{2} \mathrm{O}_{5}$ in the calcified phosphates falls between $11.0 \%-15.2 \%$. Accordingly, the phosphorite in the study area is of a low-grade type and its beneficiation and the acquiring of phosphorous concentrates become more difficult. It is better named as phosphate-bearing carbonate rocks.

\section{Acknowledgements}

Thanks are due to Deanship of Scientific Research and Higher Studies in Yarmouk University for financial support. Thanks are extended to J. Nazzal for the help of photographing under the microscope and also to the developer I. Zaayed (Biology Department). Special thanks are due to anonymous referees for critical comments. 


\section{References}

Abdel Rahman, I., \& Mansour, M. (2005). Microbial control on the mineralogy of Arief El Naqa Phosphates, Egypt. Acta Geologica Hungarica, 48(3), 339-350. http://dx.doi.org/10.1556/AGeol.48.2005.3.6

Abed, A., \& Al-Agha, M. (1989). Petrography, geochemistry and origin of the NW Jordan phosphorites. Journal of the Geological Society, 146, 499-506. http://dx.doi.org/10.1144/gsjgs.146.3.0499

Abed, A., \& Fakhoury, Kh. (1990). Role of microbial processes in the genesis of Jordanian Upper Cretaceous Phosphorites. Journal of the Geological Society, Special Publications, 52(1), 193-203. http://dx.doi.org/10.1144/GSL.SP.1990.052.01.14

Abed, A. M. (1994, August). Shallow marine phosphorite-chert-palygorskite association, Upper Cretaceous Amman formation, Jordan. In Siliceous, phosphatic and glauconitic sediments in the tertiary and Mesozoic. Proceedings of the 29th international geology congress, Part C, VSP, The Netherlands (pp. 205-224).

Al-Agha, M. (1985). Petrography, chemistry and origin of the NW Jordan phosphates (M. Sc. Thesis, p. 212). University of Jordan.

Al-Bassam, S., Aba-Hussain, A., Mohamed, I., \& Al-Rawi, Y. (2010). Petrographic Cclassification of Phosphate components of East Mediterranean phosphorite deposits. Iraqi Bulletin of Geology and Mining, 6(1), 59-79.

Al-Rifaiy, I., \& Al-Zamel, A. (1993). Foraminifera and microfacies of an exposure of the Amman Formation along the Amman/El-Salt Road, NW Amman, Jordan. Journal of the University of Kuwait (Science), 20(2), 311-324.

Al-Shereideh, S., Saqqa, W., \& abu-Jaber, N. (1997). Petrography, microfacies and geochemistry of phosphate beds in the Upper Cretaceous Amman Formation, SE Irbid. Africa Geoscience Review, 4(3\&4), 405-415.

Bathurst, R. G. C. (1971). Carbonate sediments and their diagenesis (p. 620). Amsterdam: Elsevier.

Bathurst, R. G. C. (1975). Carbonate sediments and their diagenesis. Developments in Sedimentology, 12 (p. 658). Amsterdam: Elsevier Publishing Company.

Bender, F. (1974). Geology of Jordan (p. 196). Berlin: Gebrueder Borntraeger.

Berner, R. A. (1980). Early Diagenesis: A Theoretical Approach (p.241). Princeton, New Jersey: Princeton University Press.

Cook, P. J. (1970). Repeated diagenetic calcitization, phosphatization and silicification in the Phosphoria Formation. Geological Society of America Bulletin, 81, 2107-2116. http://dx.doi.org/10.1130/0016-7606(1970)81[2107:RDCPAS]2.0.CO;2

Fakhoury, K. (1987). Chemical variability of francholites from Jordan and the role of microbial processes in phosphogenesis. (MSc. Thesis). University of Jordan, Amman.

Feng W., \& Sun W. (2003). Phosphate replicated and replaced microstructure of molluscan shells from the earliest Cambrian of China. Acta Palaeontologica Polonica, 48(1), 21-30.

Glenn, C., Arthur, M., Yeh, H., \& William, C. (1988). Carbon isotopic composition and lattice-bound carbonate of Peru-Chile margin phosphorites. Marine Geology, 80, 287-307. http://dx.doi.org/10.1016/0025-3227(88)90094-1

Glenn, C. R., Follmi, K. B., Riggs, S. R., Baturin, G. N., Grimm, K. A., Trappe, J., ... Siegmund, H. (1994). Phosphorus and phosphorites-sedimentology and environments of formation. Eclogae Geologicae Helvetiae, 87(3), 747-788.

Jahnke, P. (1984). The synthesis and solubility of carbonate fluorapatite. American Journal of Science, 284, 58-78. http://dx.doi.org/10.2475/ajs.284.1.58

Kolodny, Y. (1969). Petrology of the siliceous rocks in Mishash Formation (Negev, Israel). Journal of Sedimentary Petrology, 39, 165-175.

LeGeros, R., Trautz, O., LeGeros, J., \& Klein, E. (1967). Apatite crystallites: Effects of carbonate on morphology. Science, 155, 1409-1411. http://dx.doi.org/10.1126/science.155.3768.1409. PMid:17839613

Lucas, J., Prévôt, L., Ataman, G., \& Guendogdu, N. (1979). Etude minéralogique et géochimique de la série phosphatée du Sud-Est de la Turquie (Mazidagi-Mardin). Science Geology Bulletin, 39, $59-68$.

Lucas, J., \& Prévôt, L. (1991). Phosphates and fossil preservation. In: P. A. Allison \& D. E. G. Briggs (Eds.), Taphonomy: releasing the data locked in the fossil record. Vol. 9 of topics in geobiology, Plenum Press, 
New York.

MacDonald, M., \& Partners. (1965). East Bank Water Resources. 6 volumes. Central Water Authority, Hashemite Kingdom of Jordan.

Masri, M. (1963). Geology of the Amman - Zarqa Area. (Unpublished report: Central Water Authority, p. 33). Amman, Jordan.

Mustafa, H., Atallah, M., \& Khoury, H. (1998). The Upper Cretaceous Phosphate in NW-Jordan. Abhath Al-Yarmouk, Series of Basic Sciences and Engineering, 7, 73-114.

Mustafa, H. (2000). Fish teeth from the Upper Umm Ghudran Formation (Late Santonian) of NW-Jordan. Neues Jahrbuch für Geologie und Paläontologie, Monatshefte, 10,595-612.

Nathan, Y., \& Sass, E. (1981). Stability relations of apatites and calcium carbonates. Chemical Geology, 43, 103-111. http://dx.doi.org/10.1016/0009-2541(81)90075-9

Notholt, A. J. (1980). Economic phosphatic sediments: mode of occurrence and stratigraphical distribution. Journal of the Geological Society, 137(6), 793-805. http://dx.doi.org/10.1144/gsjgs.137.6.0793

Nriagu, J. (1983). Rapid decomposition of fish bones in Lake Erie sediments. Hydrobiologia, 106, $217-222$. http://dx.doi.org/10.1007/BF00008119

Parker, D. (1970). The hydrology of the Mesozoic - Cainozoic aquifers of the western highlands and plateau of East Jordan (4 volumes). (Unpublished technical report, No. 2, p 424). Rome: UNDP/FAO 212.

Piepenbrink, H. (1989). Examples of chemical changes during fossilization. Applied Geochemistry, 4, $273-280$. http://dx.doi.org/10.1016/0883-2927(89)90029-2

Plank, T., \& Langmuir, C. (1998). The chemical composition of subducting sediment and its consequences for the crust and mantle. Chemical Geology, 145(3-4), 325-394. http://dx.doi.org/10.1016/S0009-2541(97)00150-2

Posner, A. S., Blumenthal, N., \& Betts, F. (1984). Chemistry and structure of precipitated hydroxy-apatites. In: J. O. Nriagu., \& P. B. Moore (Eds.), Phosphate minerals (pp. 330-350). Berlin: Springer Verlag. http://dx.doi.org/10.1007/978-3-642-61736-2_11

Prévôt, L. (1990). Geochemistry, petrography, genesis of Cretaceous-Eocene phosphorites: the Ganntour deposit (Morocco): a type example. Mémoires de la Société géologique de France, Nouvelle Série, 158, 1-230.

Pufahl, P. K., Grimm, K. A., Abed, A. M., \& Sadaqah, R. M. (2003). Upper Cretaceous (Campanian) phosphorites in Jordan: implications for the formation of a south Tethyan phosphorite giant. Sedimentary Geology, 161(3-4), 75-205. http://dx.doi.org/10.1016/S0037-0738(03)00070-8

Russel, R., \& Treuman, N. (1971). The geology of the Duchess Phosphate deposits, Northwestern Queensland, Australia. Economic Geology, 66, 1186-1214. http://dx.doi.org/10.2113/gsecongeo.66.8.1186

Saadi, T. A. K. (1969). Mineralogy, crystal chemistry and genesis of some Jordanian phosphate ores (M. Sc. Thesis, p. 98). Durham University.

Sheldon, R. (1987). Association of phosphatic and siliceous marine sedimentary deposits. In: J. R. Hein (Ed.), Siliceous Sedimentary Rock-Hosted Ores and Petroleum (pp. 58-80). New York: Nostrad.

Soudry, D. (1979). Intervention de schyzophytes dans la phosphomicritization des débris osseux. Comptes Rendus de l'Académie des sciences, Paris, 288D, 669-671.

Soudry, D. (1983). Etude de la série phosphatée de la région d'Ein Yahav (Negev, Israel). Logigue séquentielle, pétrologie, approache de la phosphatogénése (Ph.D thesis, p. 177). Inst. National Polytechnique de Lorraine.

Soudry, D. (1985). Diagenetic calcitization of phosphate grains. A process leading to impoverishment of phosphorites (Central Negev, Israel). Israel Journal of Earth Sciences, 34, 222-226.

Soudry, D. (1987). Ultra-fine structures and genesis of the Campanian Negev high- grade phosphorites (southern Israel). Sedimentology, 34(4), 641-650. http://dx.doi.org/10.1111/j.1365-3091.1987.tb00792.x

Wilson, J. L. (1975). Carbonate facies in geologic history (p. 471). Berlin: Springer Verlag. http://dx.doi.org/10.1007/978-1-4612-6383-8

Wilson, N., Cline, J., \& Amelin, Y. (2003). Origin, timing and temperature of secondary calcite-silica mineral formation at Yucca Mountain, Nevada. Geochimica et Cosmochimica Acta, 67, 1145-117. 
http://dx.doi.org/10.1016/S0016-7037(02)01205-X

Wolfart, R. (1959). Geology and hydrogeology of the Irbid district (Hashemite Kingdom of Jordan). Hannover: Bundesanstalt fur Bodenforschung. PMid:13850439

Zalmout, I., \& Mustafa, H. (2001). A Selachian Fauna from the Late Cretaceous of Jordan. Abhath Al-Yarmouk, Basic Sciences and Engineering, 10(2B), 377-434.

\section{Copyrights}

Copyright for this article is retained by the author(s), with first publication rights granted to the journal.

This is an open-access article distributed under the terms and conditions of the Creative Commons Attribution license (http://creativecommons.org/licenses/by/3.0/). 